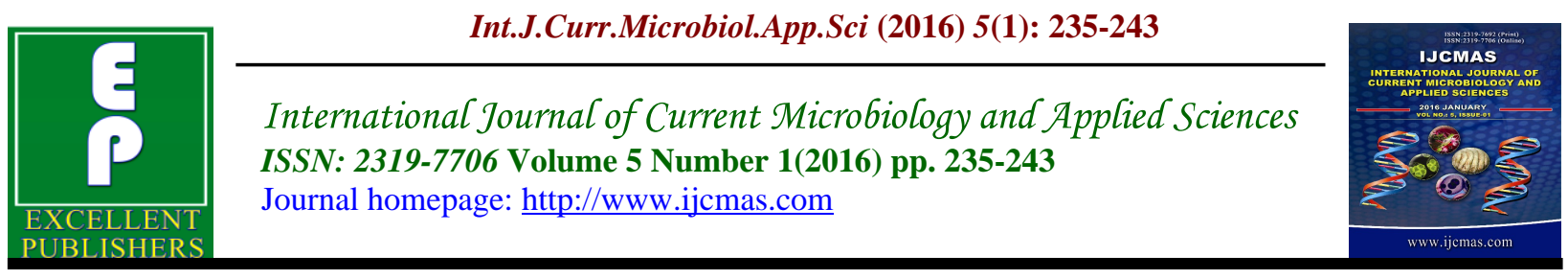

Original Research Article

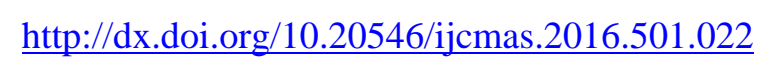

\title{
Antifungal Potential of PGPR, their Growth Promoting Activity on Seed Germination and Seedling Growth of Winter Wheat and Genetic Variabilities among Bacterial Isolates
}

\author{
Manoj Kumar Meena*, Siddhi Gupta and Soumana Datta \\ Department of Botany, University of Rajasthan, Jaipur, Rajasthan, India \\ *Corresponding author
}

\begin{abstract}
A B S T R A C T
Keywords

Chlorophytum borivilianum,

Fusarium oxysporum, UPGMA cluster method, RAPD, PGPR

\section{Article Info}

Accepted:

12 December 2015 Available Online:

10 January 2016

Plant growth promoting bacteria are the group of bacteria that colonize the rhizosphere and exert a beneficial impact on plant health and soil fertility. Microbes can directly facilitate the plant growth in several ways such as syntheses of phytohormones, enzymes or indirectly by protecting from pathogen via antagonistic activity and by minimizing effect of abiotic stress. Present study was carried out with the sample isolated from rhizosphere of plant, Chlorophytum borivilianum. Isolates that shows positive activity any of $\mathrm{N}_{2}$ fixation, phosphate solubilisation, IAA production were studied for their antagonistic activity against fungi, pot trials on wheat and RAPD of isolates was done to show relativeness. Four isolates showed antifungal activity toward plant pathogen, Fusarium oxysporum. Out of these four isolates D3 showed highest antagonistic activity against $F$. oxysporum with $89 \%$ in term of percentage inhibition. The combination of isolate A3 \& D3 significantly enhance the overall growth of wheat. UPGMA cluster method was used to generate phylogenetic tree. Study can encourage farmers to use PGPR to enhance crop productivity.
\end{abstract}

\section{Introduction}

Chemicals use is an important part of today's agriculture, but heavy reliance on chemicals often has a negative effect on soil, environment, humans, and animals and also on soil microflora. Use of chemicals in agriculture practices effect quantity and quality of agricultural production, and these interactions made an important discussion subject that called as agricultureenvironment relationships (Eser and Geçit, 2010).
There are many of plants that used for medical purposes. Matricaria recutita $\mathrm{L}$. is a well-known medicinal plant species that used in several medicinal preparations and its essential oil. It was reported that agricultural practices impact sesquiterpenic compounds of the of $M$. recutita (Petronilho et al., 2011). Animals also benefit from nature and again they effect to human directly or indirectly. It has been reported that amongst all the parameters used to 
assess the quality of hay, fungal diversity and the production of breathable dust were the most sensitive parameters to agricultural practices and climatic factors (Se'guin et al., 2010). Due to the increase in human population, fertilizers were used to increase crop production to meet rising demands for food (Gupta et al., 2014). The hazardous nature of chemical fertilizers for the environment has led to a resurgence of interest in the use of bio-fertilizers (PGPR), PGPR's can be a best alternative of chemical fertilizer for sustainable and ecofriendly agriculture. They will not only provide nutrients to the plants (direct plant growth promotion) and protect plants against the phytopathogens (indirect plant growth promotion) but also increase the soil fertility (Das et al., 2013). Rhizosphere bacteria promote plant growth directly via production of plant enzymes, solubilizing of phosphate to make available for plants, sequestering of iron by production of siderophores, production of phytohormones such as auxins, cytokinins, and gibberellins and by lowering of ethylene concentration via ACC deaminase activity (Gupta et al., 2014). Indirectly PGPRs improve the plant growth by becoming a biocontrol agents for fungal pathogen and redemption from abiotic stress like heavy metals, salt, drought, heavy rain etc.

Indirect mechanisms of PGPR, including those associated with cereal crops produce various types of antifungal metabolites capable of reducing or suppressing infection by pathogenic fungi in several crops (Ongena et al., 1999) via production of antibiotics, viz. 2,4-Diacetyl phloroglucinol (DAPG), phenazine, pyoluteorin and pyrrolnitrin against pathogenic fungi and bacteria, reduction of iron available to phytopathogens in the rhizosphere, synthesis of fungal cell wall and insect-gut membrane lysing enzymes, chitinase enzyme for hydrolysis of chitin layer of the eggshell of nematode and also competition with detrimental microorganisms for sites on plant roots and induction of systemic resistance against various pathogens and pests in plants (Ramamoorthy et al., 2001). $P$. fluorescens strains tried, stem cutting, dipping and soil application of Pf1 was found to be suitable for the management of coleus root rot under pathogen $(M$. phaseolina) inoculated soil in greenhouse condition. $M$. phaseolina is widely distributed in many countries and it is a devastating pathogen right from the establishment of the crop (Vanitha and Ramjegathesh, 2014).

The diversity of microorganisms present in the soil depends on geographical location of field, types of soil (alkaline or acidic) and also depends on the crop in the field and the type of metabolites that produce to arrest the pathogens. Further differentiation within the class of microorganism based on the chemical component can be done with the help of molecular marker. Many molecular methods are used to detect the presence of soil-borne pathogens and also to assess the genetic variability among the different isolates (kumar at el., 2002). Thakuria et al. (2004) studied three groups of rhizobacteria, isolated from the rhizosphere of rice grown in acidic soils of Assam. Isolated bacteria were selected for taxonomic identification, characterization and also for screening the superior isolates to promote rice growth. RAPD analysis of the isolates indicates distinct genotypes.

\section{Materials and Method}

\section{Soil Sample Collection}

The experimental material for the present study consists of soil samples. Collection of soil sample was done from rhizosphere of plant, Chlorophytum borivilianum along with their open areas (Gupta et al., 2014). 


\section{Bacterial Isolation, Identification and PGPR Activity}

Single colonies of bacteria were isolated by serial dilution and plate streaking methods, and partially identified on the basis of biochemical tests. PGPR activity of isolated bacteria estimated in vitro using biochemical tests (Gupta et al., 2014).

\section{Antifungal Assay}

The bacterial isolates tested for their antifungal activity were grown in the respective broth media for 24- $48 \mathrm{hrs}$. A dual culture technique using PDA medium (Dennis and Webster, 1971) were used For the testing of antifungal activity, PDA plates was prepared and after media solidification $6 \mathrm{~mm}$ well are punched into the agar medium and filled with $150 \mu$ l of bacterial culture, agar plates. Diluted spore suspension $0.1 \mathrm{ml}$ of the fusarium oxysporum was spread on pre prepared agar plates. The plates were incubated for the period of 4-5 days ate 28 ${ }^{\circ} \mathrm{C}$. The percentage growth inhibition was calculated using the following calculation:

$\%$ Inhibition $=[(\mathrm{R}-\mathrm{r}) / \mathrm{R} \times 100]$

$\mathrm{R}=$ maximum radius of the fungal colony away from the bacterial colony

$r=$ radius of the fungal colony opposite the bacterial colony

\section{Pot Experiment}

Pot experiment was conducted in plastic pots $(7.5 \mathrm{~cm}$ diameter; $9 \mathrm{~cm}$ deep) containing $250 \mathrm{gm}$ of sterilized soil. The soil has $\mathrm{pH} 8.6$, organic carbon $(0.14 \%)$, phosphate $(24 \mathrm{~kg} / \mathrm{Hec})$ and potash $(290$ $\mathrm{kg} / \mathrm{hec})$. The inoculation treatments were set-up in 5 replicates. Fresh culture of isolates were used for treatment. Wheat (Triticum aestivum) seeds were used for the petri dish experiments. Seeds were surface sterilized with $0.1 \% \quad \mathrm{HgCl} 2$ for the prevention of surface fungal/bacterial contamination. Sterilized seeds were coated with bacteria by dipping the seeds in bacterial broth. The pot experiment contained control (no inoculation) and inoculation with bacterial sample in the form of single and mix culture. Pots were incubated in open field condition at temperature $16-20^{\circ} \mathrm{C}$ (day/night) for 7 days and after a week germination percentage, shoot length, fresh weight and dry weight were calculated as seedling growth parameters.

\section{RAPD and Data Analysis}

Random amplification of polymorphic DNA was performed using 10 primers of UBC obtained from University of British Columbia, Vancouver, Canada. Genomic DNA $(20-25 \mu \mathrm{g})$ of isolates were used as template and PCR amplification was performed in a $25 \mu \mathrm{l}$ reaction mixture containing Taq Buffer $2.5 \mu \mathrm{l}$ (10X Assay Buffer (Bangalore Genei)), dNTPs 2.0 $\mu 1$ $(200 \mu \mathrm{M}$ each of dNTPs (Fermentas)), Taq pol. 0.5U (Bangalore Genei), Primer 4.0 $\mu 1$ (UBC Set \# 2), Template $2.0 \mu \mathrm{l}, \mathrm{MgCl} 20.5$ $\mu \mathrm{l}$, and DDwater 14.0 $\mu \mathrm{l}$. PCR reactions were carried out in a DNA thermal cycler (Model-CGI-96, Corbett Research, and Australia) using a single primer in each reaction. The amplification condition was as follows: Initial denaturation $\left(94^{\circ} \mathrm{C}\right) \quad 4$ Minutes followed by Cycle $1-44$ Denaturation $\left(94^{\circ} \mathrm{C}\right)$ for 1 Minute, Primer annealing $\left(37^{\circ} \mathrm{C}\right)$ for 1 Minute, Primer Extension $\left(72^{\circ} \mathrm{C}\right)$ for 2 Minutes. A final extension was carried out at $72^{\circ} \mathrm{C}$ for 7 Minutes. Following the amplification, the PCR products were loaded on 1.2\% Agarose gel (Himedia, molecular grade), which was prepared in $1 \mathrm{X}$ TBE buffer containing 0.5 $\mu \mathrm{g} / \mathrm{ml}$ of the Ethidium Bromide. The amplified products were electrophoresed for $3-3.5 \mathrm{hrs}$ at $100 \mathrm{~V}$ with cooling. 
In order to score and preserve banding pattern a photograph of gel was taken by digital photography system, under UV Transilluminator. The distance run by amplified fragments from the well was translated to molecular sizes with reference to a molecular weight marker. The presence of each band was scored as ' 1 ' and its absence as ' 0 '. Faintly visible bands were not scored, but a major band corresponding to faint band was considered for scoring. In order to confirm the presence of bands and determine reproducibility, all the primers were replicated twice and if necessary thrice.

The scores ( 0 or 1$)$ for each band obtained from photograph were entered in the form of a rectangular data matrix (qualitative data matrix). The pairwise association coefficients were calculated from the qualitative data matrix using Jaccard's similarity coefficient. Cluster analysis for the genetic distance was then carried out using UPGMA (Unweighted Pair Group Method with Arithmetic Mean) clustering method. The genetic distances obtained from cluster analysis through UPGMA were used to construct the dendrogram, depicting the relationships of the clones using computer program NTSYS pc version 2.02 (Rohlf, 1998).

\section{Results and Discussion}

Bacterial Isolation, Identification and PGPR Activity

\section{Antifungal Activity (\% Inhibition)}

\section{Pot Experiment}

Only Isolates A3 and D3 was used for pot experiment because of their multiple PGPR activity. The results indicated that the percentage of the germination of wheat seed was significantly increased under the influence of the PGPR and the overall growth parameters also indicates that a combination of isolate A3 and D3 give the best result.

\section{RAPD and Dendrogram}

All the ten bacterial isolates were examined for random amplified polymorphic DNA (RAPD) markers with 15 decamer primers. Only the bands showing reproducible amplification were considered for scoring and for further analysis. Out of 10 amplifying primers 6 produced polymorphic bands. The total number of bands generated by ten amplifying primers was 53 with an average amplification of 5.3 bands per primer. The average polymorphism generated by these bands was $32.08 \%$. The size of the amplicons generated varied from 200bp to 4000bp.

Current soil management strategies are mainly dependent on inorganic chemicalbased fertilizers, which caused a serious threat to human health and environment. The exploitation of beneficial microbes as a Bio-fertilizer has become paramount importance in agriculture sector for their potential role in food safety and sustainable crop production. Table 1 shows the summaries result of biochemical test and direct plant growth promoting activity $\left(\mathrm{N}_{2}\right.$ fixation, IAA production, Phosphate solubilisation) of isolates (Gupta et al., 2014).

The D3 \& A5 isolates was characterized with the highest antagonistic activity against the tested pathogen fungi ( $F$. oxysporum). The biocontrol agent, several strains of $B$. subtilis produce cyclic lipopeptides, which belong to the family Iturin. Iturin and other antibiotics of their family bacillomycin L, bacillomycin $\mathrm{D}$, bacillomycin $\mathrm{F}$ and 
mycosubtilins are powerful antifungal agents (Constantinescu, 2001). Production of these antifungal compounds and their association with the inhibition or biocontrol of different fungal plant pathogens was also reported by Leclère et al. (2005).
Antifugal antibiotics Phenazines, Phenazine1-carboxylicacid, Phenazine-1-carboxamide, Pyrrolnitrin (Pierson and Pierson, 1996) and sulphonamide produced by rhizobacteria Pseudomonas sp. (Kim et al., 2000).

Table.1 Summarize Result of Identification and PGPR Activity of Isolates Gupta et al., 2014

\begin{tabular}{|c|c|c|c|c|c|c|c|c|c|c|}
\hline $\begin{array}{c}\text { S. } \\
\text { No. }\end{array}$ & $\begin{array}{c}\text { Test } \\
\text { sample }\end{array}$ & $\begin{array}{c}\text { Grams } \\
\text { staining }\end{array}$ & $\begin{array}{l}\text { Colony } \\
\text { colour }\end{array}$ & $\begin{array}{l}\mathrm{H} 2 \mathrm{~S} \\
\text { produc } \\
\text { tion }\end{array}$ & $\begin{array}{l}\text { Mot- } \\
\text { ility }\end{array}$ & $\begin{array}{c}\text { Methyl } \\
\text { red } \\
\text { test }\end{array}$ & $\begin{array}{c}\mathrm{N} 2 \\
\text { Fixation } \\
\text { (Broth) }\end{array}$ & $\begin{array}{c}\mathrm{N} 2 \\
\text { Fixation } \\
\text { (agar) }\end{array}$ & $\begin{array}{c}\text { IAA } \\
\text { production }\end{array}$ & $\begin{array}{l}\text { Phosphate } \\
\text { solubilizing }\end{array}$ \\
\hline 1 & S-29 & + & $\begin{array}{l}\text { Light } \\
\text { brown }\end{array}$ & + & - & + & + & + & - & - \\
\hline 2 & A3 & - & Yellowish & - & + & + & + & - & $\begin{array}{c}+(100 \mathrm{ng} / \\
\mu \mathrm{l})\end{array}$ & - \\
\hline 3 & D3 & - & Yellowish & - & + & - & - & + & - & $\begin{array}{c}+(61.71 \mathrm{~mm} \\
\text { diameter })\end{array}$ \\
\hline 4 & $\mathrm{C} 1$ & + & $\begin{array}{l}\text { Pale } \\
\text { colour }\end{array}$ & + & - & - & + & + & - & - \\
\hline 5 & $\begin{array}{c}\text { B1-01- } \\
64\end{array}$ & + & $\begin{array}{l}\text { Light } \\
\text { brown }\end{array}$ & + & + & + & + & + & - & - \\
\hline 6 & D2 & + & $\begin{array}{l}\text { Pale } \\
\text { colour }\end{array}$ & + & + & - & + & + & - & - \\
\hline 7 & $\begin{array}{c}\text { PGPR } \\
20\end{array}$ & + & $\begin{array}{c}\text { Pale } \\
\text { colour }\end{array}$ & + & - & + & + & + & - & - \\
\hline 8 & S-26 & + & Yellowish & - & - & + & - & + & - & - \\
\hline 9 & A5 & - & Yellowish & - & + & + & + & + & - & - \\
\hline 10 & S-9 & - & $\begin{array}{l}\text { Light } \\
\text { brown }\end{array}$ & + & + & - & + & + & - & - \\
\hline
\end{tabular}

Table.2 Among 10 Isolates only Four Isolates were Show Antagonistic Activity against Fungus in which D3 shows Maximum \% Inhibition with 89\%

\begin{tabular}{|c|c|c|c|c|c|c|c|c|c|c|}
\hline S. No. & 1 & 2 & 3 & 4 & 5 & 6 & 7 & 8 & 9 & 10 \\
\hline $\begin{array}{c}\text { Test } \\
\text { sample }\end{array}$ & S-29 & A3 & D3 & C1 & $\begin{array}{c}\text { B1- } \\
01-64\end{array}$ & D2 & $\begin{array}{c}\text { PGP } \\
\text { R 20 }\end{array}$ & S-26 & A5 & S-9 \\
\hline $\begin{array}{c}\% \\
\text { inhibition }\end{array}$ & - & $55 \%$ & $89 \%$ & - & - & - & $46 \%$ & - & $78 \%$ & - \\
\hline
\end{tabular}


Fig.1 Antifungal Activity of PGPR via a Dual Culture Technique using PDA Medium
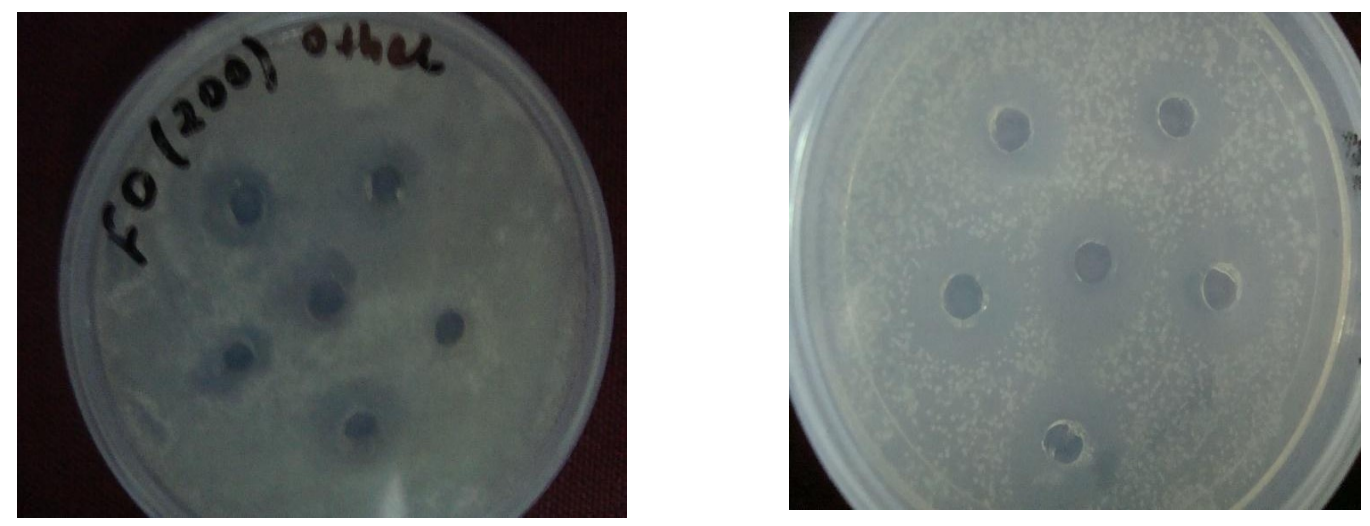

Fig.2 Dendrogram Based on Similarity Index Data Derived from the RAPD Marker Analysis on Bacterial Isolates D2, A3, A5, D3, PGPR20, S-29, S-26, S-9, B1-01-64 and C1

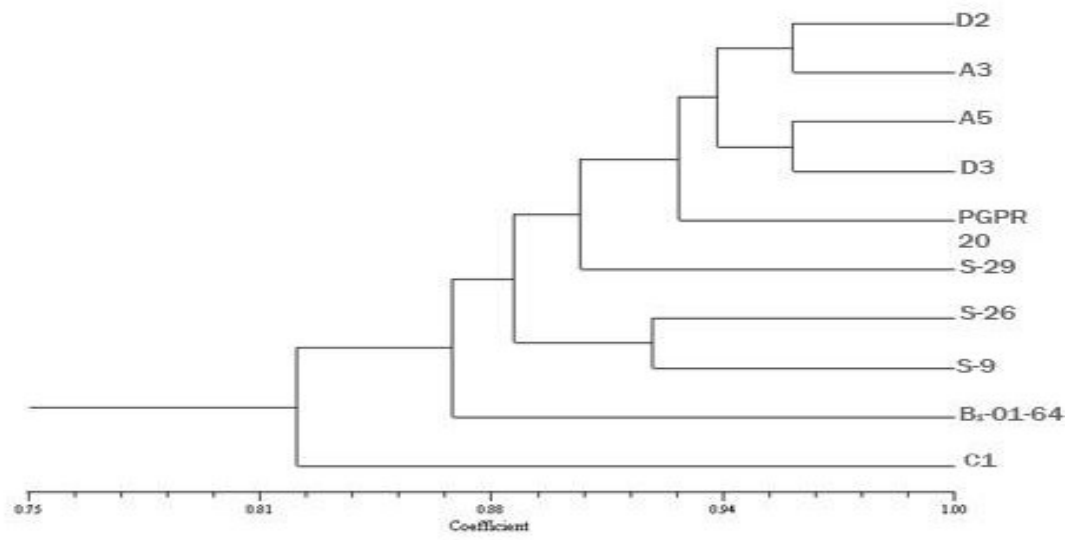

Graph.1 The rate of Germination and Shoot Length of Wheat in Various Treatment of PGPR

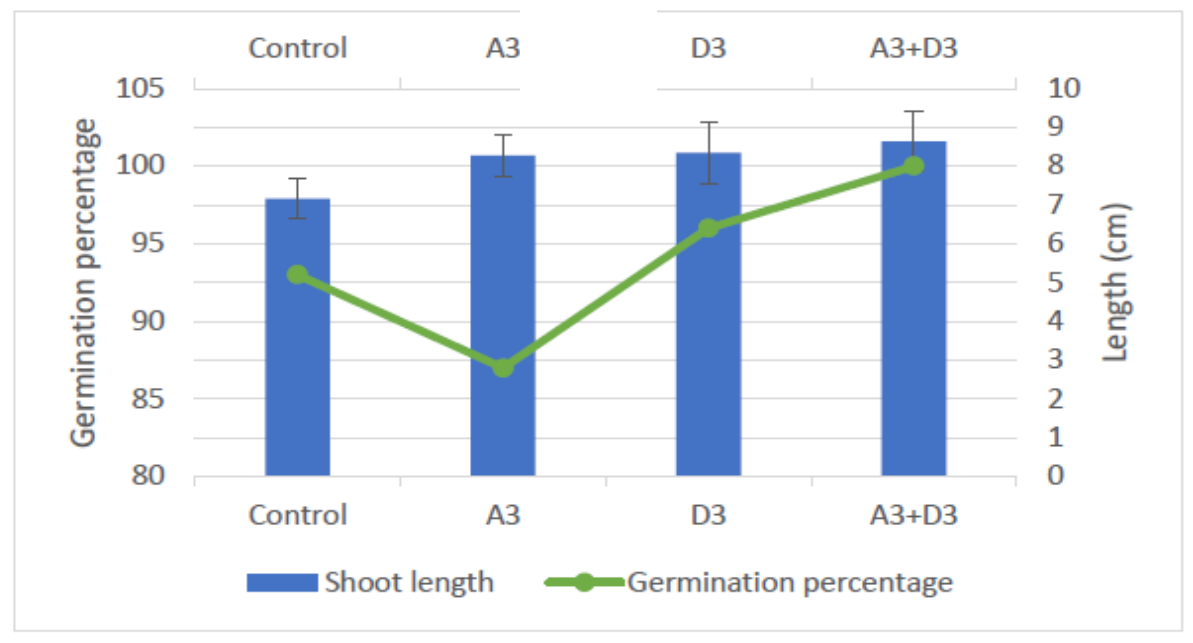




\section{Graph.2 The Average of Fresh Weight and Dry Weight of Wheat Seedling in Various Treatment of PGPR}

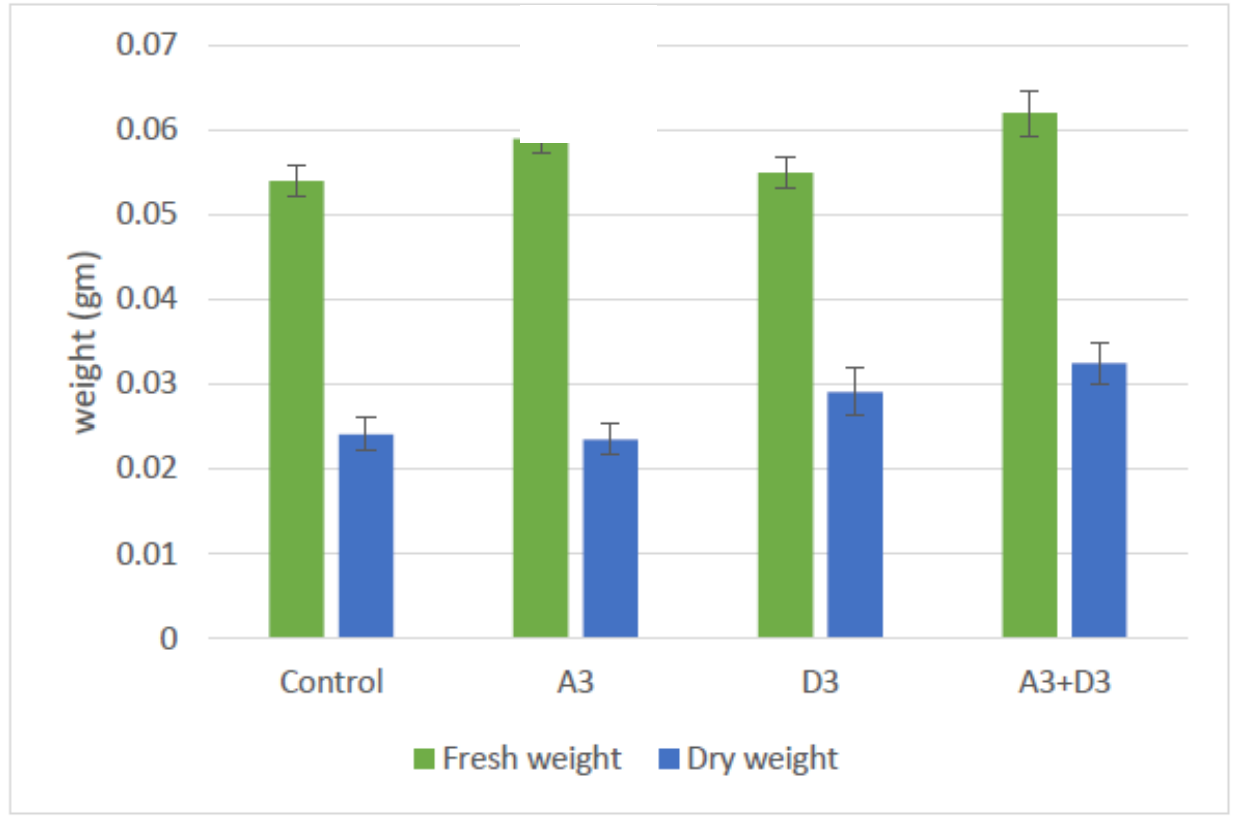

Isolates A3 and D3 are selected for pot experiment on the basis of their multiple direct/indirect growth promoting activity. Graph 1and 2 indicates the isolates A3 and D3 separately enhance the growth of wheat (increase in seedling length, seed germination, fresh weight and dry weight) and the combination of $\mathrm{A} 3$ and $\mathrm{D} 3$ gives the more significant results. Egambedieva D., (2010) was observed the shoot, root length and dry weight of wheat cultivar were significantly stimulated by bacterial strains, whereas Pseudomonas spp. NUU1 significantly increased only shoot growth and $P$. fluorescens NUU2 only dry weight of wheat cultivar Residence. Activity of Azotobacter in increasing nitrogen, biomass and grain yield of wheat was showed by Chaudhary et al. (2013).

Microbial community in the plant rhizosphere soil is highly dynamic. Relative abundance of the microbial population in plant rhizosphere soil types and environmental conditions. Fig. 1 dendrogram based on similarity index data derived from the PCR (RAPD) marker analysis on bacterial isolates the dendrogram was constructed based on the PCR data by UPGMA cluster method. DNA- based (genotypic) approach have increasingly been applied to microbial identification \& classification (Schutte et al., 2008).

Inoculation of wheat seeds with combination of isolates mention above has direct positive effects on root, shoot growth, percentage of seed germination and biomass yield. The use of these bacteria strains offers a way to reduce chemical fertilizers doses and one step forward to organic farming.

\section{References}

Chaudhary, D., Narula, N., Sindhu S. S., and Behl, R. K. 2013. Plant growth stimulation of wheat (Triticum aestivum L.) by inoculation of salinity tolerant Azotobacter strains. Physiology and Molecular Biology of Plants. 19(4):515-519. 
Constantinescu, F. 2001. Extraction and identification of antifungal metabolites produced by some $B$. subtilis strains. Analele Institutului de Cercetari Pentru Cereale Protectia Plantelor 31: 17-23.

Das, A.J., Kumar, M., and Kumar R. 2013. Plant Growth Promoting Rhizobacteria (PGPR): An Alternative of Chemical Fertilizer for Sustainable, Environment Friendly Agriculture Research Journal of Agriculture and Forestry Sciences. Vol. 1(4).

Dennis, C., and Webster J. 1971. Antagonistic properties of species groups of Trichoderma L. Production of non-volatile antibiotics. Transaction of British Mycological Society 57: 25-39.

Egambedieva, D. 2010. Growth response of wheat cultivars to bacterial inoculation in calcareous soil. Plant soil environ, 56(12): 570-573

Eser D., and Geçit, H. 2010. Ekoloji. A.Ü. Ziraat Fakültesi. 1584, Ders Kitab1: 536.

Gupta, S., Meena, M.K., and Datta, S. 2014. Isolation, characterization of plant growth promoting bacteria from the plant Chlorophytum borivilianum and in-vitro screening for activity of nitrogen fixation, phospthate solubilization and IAA production. Int. J. Curr. Microbiol. App. Sci 3(7):1082-1090

Kim, B. S., Lee, J. Y., and Hwang, B. K. 2000. In vivo control and in vitro antifungal activity of rhamnolipid $\mathrm{B}$, a glycolipid antibiotic, against Phytophthora capsici and Colletotrichum orbiculare. Pest Manage. Sci. 56: 1029-1035.

Kumar, N.R., Arasu, V.T., and Gunashekaran, P. 2002. Genotyping of antifungal compounds producing rhizobacteria Pseudomonas fluorescens. Current Science. 28:1463-1466.

Leclère, V., Béchet, M., Adam, A., and Guez, J.S. 2005. Mycosubtilin overproduction by Bacillus subtilis BBG100 enhances the organism's antagonistic and biocontrol activities. Appl. Environ. Microbiol. 71: 45774584

Ongena, M., Daayf, F., Jacques, P., Thonart, P., Benhamou, N., Paulitz, T.C., Cornelis, P., Koedam, N., Belanger, R.R. 1999. Protection of cucumber against Pythium root rot by fluorescent pseudomonads: predominant role of induced resistance over siderophores and antibiosis. Plant Pathol. 48:66-76

Petronilho, S., Maraschin, M., Delgadillo, I., Coimbra, M.A., and Rocha S.M. 2011. Sesquiterpenic composition of the inflorescences of Brazilian chamomile (Matricaria recutita L.): Impact of the agricultural practices. Industrial Crops and Products. 34: 1482- 1490.

Pierson, L.S., and Pierson, E.A. 1996. Phenazine antibiotic production on Pseudomonas aureofaciens: role in rhizosphere ecology and pathogen suppression. FEMS Microbiol. Lett. 136: 101-108.

Ramamoorthy, V., and Samiyappan, R. 2001. Induction of defense-related genes in Pseudomonas fluorescens treated chilli plants in response to infection by Colletotrichum capsici. J. Mycol. Plant Pathol. 31: 146-155.

Rohlf, F.J. 1998. NTSYS-pc, version 2.02 f, Numerical taxonomy and multivariate analysis system. Exeter Software, New York.

Schutte, U.M.E., Abdo, Z., Bent, S.J., Shyu, C., Willians, C.J., Pierson, J.D., and Forney, L.J. 2008. Advances in the use of terminal restriction fragment 
length polymorphism (T-RLP) analysis of $16 \mathrm{~S}$ rRNA genes to characterize microbial communities. Applied microbial biotechnology 80: 365-380.

Se'guin, A. V., Lavenant S. L., Garon, D., Bouchart, V., Gallard, Y., Blanchet, B., Diquelou, S., Personeni, E., Gauduchon, P., and Ourry, A. 2010. Effect of agricultural and environmental factors on the hay characteristics involved in equine respiratory disease. Agriculture,
Ecosystems and Environmen.135: 206-215.

Thakuria, D., Talaudkar, N. C., Goswami, C., Hazarika, S., Boro, R. C., and Khan, M. R. 2004. Characterization and screening of bacteria from rhizosphere of rice grown in acidic soils of Assam. Current Science. 86(7): 978-984.

Vanitha, S. and Ramjegathesh, R. 2014. Bio Control Potential of Pseudomonas fluorescens against Coleus Root Rot Disease J Plant Pathol Microb 5:1.

\section{How to cite this article:}

Manoj Kumar Meena, Siddhi Gupta and Soumana Datta. 2016. Antifungal Potential of PGPR, their Growth Promoting Activity on Seed Germination and Seedling Growth of Winter Wheat and Genetic Variabilities among Bacterial Isolates. Int.J.Curr.Microbiol.App.Sci. 5(1): 235-243

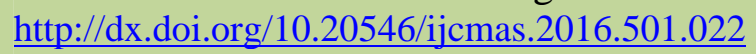

